\title{
POlítica CRIMINAL, CONSTITUIÇÃO E PROCESSO PENAL: Razões da Caminhada Brasileira para a Institucionalização do Caos
}

\author{
CRIMINAL POLICIES, CONSTITUTION AND CRIMINAL PROCEEDING: Reasons of Brazilian step out \\ to Chaos Institutionalization
}

Mauricio Zanoide de Moraes

\begin{abstract}
Resumo:
O Estado brasileiro passa por um instante de aguda crise de legitimidade em sua política criminal. Esta situação ficou evidenciada pela falta de controle eficaz e preventivo da segurança pública, notadamente nos grandes centros urbanos. Portanto, imperioso analisar em que consiste uma política criminal, de onde ela nasce, qual seu conteúdo e sua finalidade. Assentadas essas premissas, verificou-se que não há uma verdadeira política criminal brasileira. Com isso, foram expostas as principais causas e conseqüências da inexistência dessa política criminal, para dai extrair-se que a principal barreira a ser vencida é a falta de legitimidade que hoje sofrem as instituições públicas que atuam na esfera criminal. Para a busca dessa legitimidade perdida, não há melhor pressuposto legal que os princípios fundantes de nossa atual Constituição, complementado pelos Tratados Internacionais de Direitos Humanos incorporados em nosso ordenamento. Com essa basc epistemológica, a participação popular deve ser agregada à formação de uma politica criminal para a área do processo penal, nos moldes das experiências de outros países, por meio de uma pauta de princípios estabelecidos pelo Poder Legislativo (lei delegante ou-não) a serem cumpridos por uma comissão de técnicos responsáveis pela redação de um novo ('ódigo de Processo Penal.
\end{abstract}

Palavras-chave: Política criminal. Processo penal. Constituição. Tratados internacionais. Legitimidade do sistema punitivo. Crise de legitimidade. Direito criminal. Política e sociedade. Poder político.

Abstract:

Brazilian State faces a period of sharp legitimacy crisis in its criminal policy. This situation is evidenced by the absence of effective and preventive controls in public security, notably in large urban centers. So, on must analyze what a criminal policy means, its origins, content and goals. After having defined these assertions, on realized that there's not real Brazilian criminal policies. On exposed main causes and consequences of the absence of Brazilian criminal policies, in order to conclude that the main obstacle to be overcome is the absence of legitimacy of public institutions that act in criminal sector. In the search of this lost legitimacy, the best legal assertion is fundamental principles of our present Constitution, completed by International Human Rights Treaties, inserted in our legal ordainment. With this epistemological basis, popular participation should be added

Professor Doutor de Processo Penal do Departamento de Direito Processual da Faculdade de Direito da I nniversidade de São Paulo. Presidente do Instituto Brasileiro de Ciências Criminais. Advogado Criminal. e-mail: mzmoraes@zanoideadvogados.com.br. 
to the formation of a criminal policy for criminal proceedings, according to foreign models, throughguidelines of principles established by the Legislative Power (delegating law or not) to be observed by a commission of technicians responsible for the drafting of a new Criminal Proceeding Code.

Keywords: Criminal Policy. Criminal Proceeding. Constitution. International Treaties. Legitimacy of Punitive System. Legitimacy Crisis. Criminal Law. Politics and Society. Political Power.

Há uma completa e generalizada insatisfação com os instrumentos legais utilizados pelo Estado para o tratamento dos conflitos criminais. Não há agente público, operador do Direito Criminal, professor universitário ou cidadão que esteja satisfeito com o aparato hoje existente no ordenamento brasileiro, seja em sua estruturação seja em sua coerência e resultado.

O sentimento, embora uníssono quanto à insatisfação, é diversificado quanto às críticas e às propostas de aperfeiçoamento. Há quem entenda que a eficiência viria de uma maior qualidade e quantidade de punição, há outros que entendem que o sistema está em colapso porque se pune demais. Há quem afirme que a insegurança pública advém da forma de escolha valorativa de "quem", "porque" e "como" punir, pois é marginalizante e seletiva, enquanto outros entendem que aquela insegurança cresce porque a criminalização é leniente e lassa.

Por outro lado, há quem dirija suas críticas não à criminalização (Direito Material Penal), mas à persecução e execução criminal (Direito Processual Penal). Nesse contexto, as críticas vão do sistêmico ao pontual. Como crítica sistêmica, afirma-se a inconstitucionalidade do Código de Processo Penal vigente - nascido em matriz inquisitiva de 1941 - em face do sistema acusatório determinado cogentemente pela atual Constituição da República. promulgada em 1988, com expressa preceituação de direitos e garantias aos investigados/acusados. Pontualmente, ressalta-se a interpretação seletiva e/ou marginalizante contida na variação hermenêutica' de uma mesma norma processual, conforme a ideologia do operador do Direito que participe do feito e as

A variaçào de entendimentos jurisprudenciais quanto a qualquer norma processual penal estendendo ou reduzindo sua incidência e, em certos casos, até mesmo negando-lhe vigència formal ou material, pode ser constatada pela enorme quantidade de obras especializadas em coletâneas de arestos de nossos Tribunais. Como eximplo dessa multiplicidade interpretativa de nosso Tribunais $\therefore$. a obra de FRANCO. Alberto Silva [ct al]. Código de processo penal e sua interpretaçáo jurisprudencial - doutrina e jurisprudência. 2. ed. rev., atual. e ampl. São Paulo: Revista dos Tribunais. 2004. 
características pessoais do cidadão ${ }^{2}$ (vítima ou suspeito/acusado/executado) envolvido na causa.

No âmbito processual também há os que o utilizam para punir mais e outros que o entendem como forma de controle do poder estatal de punir.

Da variabilidade das críticas, que vai desde os juristas até o cidadão comum, passando pelos agentes públicos (legisladores, juízes e administradores), decorre uma incoerência (às vezes esquizofrenia) legislativa e uma ineficiência jurisdicional e administrativa, as quais não cumprem minimamente seu papel de ao menos controlarem a insegurança pública.

A insegurança pública, surgida e alimentada por aquelas mazelas, deixa seu locus de objeto de análise e implementação de políticas públicas para sua eliminação e passa a ser determinadora dos atos estatais (legislativos, executivos e jurisdicionais). Deixa de ser limitada pelos atos dos agentes públicos e passa a determiná-los.

Nesse instante de inversão da lógica político-social, pela qual a violência não é limitada pelos atos públicos, mas sua indutora, o Estado, como ente político, deslegitima-se a cada instante e a cada ato porquanto não conduz, mas é conduzido. A aceitação dessa situação político-social por um longo período leva à neutralização da análise científica e à institucionalização do caos no trato público das questões criminais.

Conduz à neutralização da análise científica, porque todas as correntes técnico-ideológicas se deslegitimam com o tempo; porquanto, não são aplicadas de forma ampla a todo o sistema jurídico-criminal, mas de forma pontual e, no mais das vezes, sem recursos estatais suficientes ou sem a necessária mudança de mentalidade dos operadores do Direito para sequer uma tentativa de implementação. ${ }^{3}$

Conduz à institucionalização do caos porque, ao não oferecer uma opção político-cientifica legitimada à sociedade. "autoriza-a" a agir por conta e risco para a solução pontual de seus conflitos. Aos mais abastados, "permite" um policiamento e militarização particulares, aos mais pobres, "tolera" a ação de grupos de extermínio. justiceiros. linchamentos ou atos criminosos pontuais, que transbordam a legítima defesa e partem para a violenta "proteção" da comunidade. De qualquer modo que se examine a

Quanto à vitima, basta ver o alto grau de eficiência punitiva quando ela é agente público ou pessoa com grande importància social. Quanto ao investigado, acusado e condenado, basta ver o perfil social, ćconômico e educacional do público dos presidios nacionais.

3 Como exemplo de um bom sistema legal que foi paulatinamente perdendo a legitimidade por falha das instituiçōes que deveriam aplicá-lo tome-se o Código de Trânsito Brasileiro (Lei n. 9.503/97). Este códex, por sua clara sistemática. finalidade e coerência, além de scu recrudescimento de sanções administrativas e penais, incluindo novos crimes e um inovador sistema de pontuação para perda ou suspensão do direito de dirigir. cuntou com grande aceitação popular $\mathrm{c} f \mathrm{c} z \mathrm{com}$ que o número de acidentes de trânsito diminuisse. Com o passar do tempo. pela falta de estrutura das instituições públicas para bem aplicá-lo, ocorreu a sua paulatina deslegitimaçào e o número de acidentes voltou a aumentar. 
questão, o caos institucionalizado faz com que o ser humano abandone o pouco de evolução social e humana conseguida durante séculos de existência e retorne à barbárie humana do combate da violência pela violência.

Dessarte, a reversão do processo paulatino de violência urbana passa por uma atuação estatal legitimada e legalizada, o que somente poderá ser alcançado pela fixação de padrões seguros e socialmente aceitos de uma (nova) política criminal, cujo objetivo primaz deve ser a redução e o controle da criminalidade.

\section{Política e Sociedade}

O homem, ser gregário por imanência, somente consegue desenvolver-se e manter sua espécie no convívio social. É no grupamento que o homem se completa e se realiza como ser. Mas é nesse mesmo grupamento, devido aos múltiplos e variados choques e relações com os demais indivíduos, que mais surgem situações propícias a aflorar suas imperfeições e violências. A sociedade, ao mesmo tempo que é uma necessidade ao desenvolvimento humano, é, outrossim, um dos focos de seus problemas.

A sociedade, entendida nesse passo como grupamento humano no qual se estabelecem conflitos interindividuais variados e pluralidade de designios, sempre precisou de diretrizes de comportamento e de um quociente de coerção para se manter integrada e progressiva. Não há grupamento humano que se desenvolva e garanta o bemestar de seus integrantes, sem que haja um direcionamento claro à realização de um fim benéfico e comum ao grupo.

A ordem, ${ }^{4}$ entendida como o direcionamento escolhido para o grupo, por mais legitimado que seja por todos ou pela significativa maioria dos seus integrantes, não está imune a atos que a contrariem. Por mais coesão voluntária e maior harmonia entre as pessoas, não há como se evitar ${ }^{5}$ atos de violência que atingem importantes bens da vida àquela sociedade.

A escolha desses bens como mais ou menos relevantes faz parte da definição dayuele direcionamento desejado pelo grupo; a tutela em maior ou menor grau, com maior ou menor coerção. determina, respectivamente. o âmbito do ilícito e a intensidade da sanção a seu agente. Dentre as várias espécies de ilícitos, é reservada a

1 Para a idéia de ordem pública como ao menos um fím minimo da Politica, v. POI.íTICA. In: BOBBIO, Norberto. Dicionário de politica. Traduçào Carmem C. Varrialle. Gaetano Lo Mônaco, Joāo Ferreira, Luís Guerreiro Pinto Cascais e Renzo Dini. 5. ed. Brasília:UNB, 2004, v. I. p. 958.

$5 \quad$ No convicio social, mesmo nas sociedades mais pacíficas, a imperfeição do homem o sujeita ao cometimento de crimes. Assim, mesmo com um consenso unânime quanto à aceitação e ao cumprimento da lei e um respeito absoluto ao semelhante. nảo se está imune a crimes cometidos na forma culposa, em que o evento danoso à sociedade (ilicito penal) ocurre não por desejo do agente mas por violação do dever de cuidado. 
categoria de crime ao de maior danosidade social; para ele aplica-se a mais severa punição, a sanção penal.

O surgimento inevitável do crime, assim como a sua punição, são males dos quais as sociedades modernas não conseguem se livrar, muito ao contrário, aumentam e assumem novas formas com a modernização acelerada.

Nesse limitado espectro dos problemas sociais representado pela criminalidade, a questão não é se o crime pode ou-não ser definitivamente eliminado. ${ }^{6}$ Mas como ele deve ser reduzido ao mínimo ou a padrões aceitáveis. Nesse passo é importante entendermos o papel que a política exerce nas sociedades modernas.

Para além da concepção clássica,? filosoficamente a política pode ser entendida como a "gestão dos conflitos, das relações de forças e do poder" em uma sociedade. É "a atividade ou o conjunto de atividades que, de alguma maneira, têm como termo de referência a pólis, ou seja, o Estado. Dessa atividade a pólis é, por vezes, o sujeito, quando referidos à esfera da Política atos como o ordenar ou proibir alguma coisa com efeitos vinculados para todos os membros de um determinado grupo social, o exercicio de um domínio exclusivo sobre um determinado território, o legislar através de normas válidas erga omnes, o tirar e transferir recursos de um setor da sociedade para outro, etc.; outras vezes ela é objeto, quando são referidas à esfera da Política ações como a conquista, a manutenção, a defesa, a ampliação, o robustecimento, a derrubada, a destruição do poder estatal, etc." 9

Política, portanto, é esse atuar em cada espectro da vida da pólis e, também, cada parcela da vida do grupamento faz com que a Política assuma contornos peculiares e com cada qual mais afim. Assim, tem-se dentro de um mesmo Estado a política social, a política educacional, a política econômica, a política externa, a política bélica, etc. Todas são parcelas de um aspecto geral de Política que podemos denominar Política de Estado, a qual deve ser perene, coerente entre aquelas suas múltiplas facetas, e apta a mostrar de forma clara e segura uma finalidade e um objetivo que deve ter a aprovação de todos ou ao menos da maioria de seus membros.

6 Para demonstrar a impossibilidade prática de existir sociedade sem crime, mas apenas uma possibilidade e providências eficazes para sua redução v. a análise paralela entre a obra A l topia, de Thomas Monus, e a Lei dos crimes hediondos, no texto de BATISTA. Nilo. A politica criminal d'A Utopia e a maldição de hedionduras. In: Novas tendências do direito penal. Rio de Janeiro: Revan, 2004.

7 BOBBIO, Norberto. Dicionário de politica. Tradução Carmem C. Varrialle, Gaetano Lo Mônaco, João Ferreira, Luis Guerreiro Pinto Cascais e Renzo Dini. 5. ed. Brasilia:LNB, 2004, v. l. p. 954-955, destaca que de há muito já se superou a concepção aristotélica de politica como tudo o que se refere à cidade ("pólis"), passando a se relacionar com a idéia de Estado.

* COMTE-SPONVILlE. André. Dicionário Filosófico. Tradução de Eduardo Brandão. São Paulo: Martins Fontes, 2003. p. 459.

- BOBBIO, Norberto. Dicionário de politica. Tradução Carmem C. Varrialle. Gaetano Lo Mônaco, Joào Ferreira, Luis Guerreiro Pinto Cascais e Renzo Dini. 5. ed. Brasilia:UNB, 2004, v. I. p. 954 
Passada a primeira fase de colheita da finalidade e da forma para a consecução do desígnio coletivo, a Política de Estado passa a uma segunda fase de implementação daqueles fins por todos e para todos, inclusive para e pelos agentes públicos. Nessa segunda fase é que desponta com mais ênfase a idéia de poder na Política. Poder entendido como controle de meios necessários para que uns (os detentores do poder momentânea ou perenemente) imponham aos outros (subordinados ao poder) um comportamento. ${ }^{10}$

Toda relação político-social é uma relação de poder, não há sociedade que prescinda da política e não há política sem exercício de poder, logo, em qualquer grupamento social há inevitável relação de poder político ${ }^{11}$ de uns, em face dos outros.

O poder político utiliza a força, a coerção estatal, para ver obedecidas suas escolhas valorativas como as relevantes para o grupo. Será maior a necessidade de coerção quanto menor for o grau de consenso que o grupo empreste àquelas escolhas. Quanto maior a legitimidade das escolhas políticas, menor o grau de coerção, quanto menor a legitimidade, maior a força a ser empreendida pelo agente estatal.

Se o consenso total e absoluto de todos os integrantes não é possível na sociedade moderna, o que se busca é um consenso majoritário e que determine o bemestar da maioria do corpo social. Deste modo. descartamos a imposição axiológica da minoria detentora do poder, em detrimento e com o sacrifício da maioria integradora do corpo social. Essas opções políticas, sempre implementadas com grande forma coercitiva estatal, somente existem para manter o controle dos subordinados de sempre, a fim de perpetuar o poder pelo poder. Não legitimam uma atuação política.

A legitimidade não deve ser buscada, portanto, tendo como padrão as escolhas feitas pelos detentores do poder, isto porque, isso não é uma legitimação autêntica, mas artificialmente construída e imposta por quem deve ser legitimado em seus atos, não se legitimar por eles. Os detentores do poder devem estar nesta condição por serem merecedores desse status devido à sua percepção das necessidades sociais,

10 Sobre a idéia de poder e sua inerência à concepção de Política v.. por todos, BOBBIO, Norberto. Dicionário de politica. Tradução Carmem C. Varrialle, Gaetano Lo Mônaco, Joào Ferreira, Luis Guerreiro Pinto Cascais e Renzo Dini. 5. ed. Brasilia:UNB, 2004, v. I. p. 955.

$"$ O poder e a política se relacionam de várias formas, dai surgem. p.ex.. o poder ideológico, o poder econômico, o poder bélico. etc. Mas, dentre todas as formas de poder na analise politica, o poder politico $i$ o mais relevante, dado que, poder utilizado pelos agentes públicos para determinar o comportamento dos socialmente subordinados. $\dot{E}$ o poder que condiciona e determina forma de ação ou umissão como certas ou erradas. É no poder politico que sc insere o poder penal. Sobre poder politico e suas implicações e riscos v. FILOMENO, José Geraldo Brito. Teoria geral do estado e ciência politica. 4. ed. Rio de Janeiro: Forense Universitária. 2001. item 14; BINDER, Alberto M. Politica criminal de la formulaciun a la práxis. Buenos Aires: Ad-Hòc, 1997. item I.I; e, ainda e mais uma vez, BOBBIO, Norberto. Dicionário de politica. Tradução Carmem C. Varrialle, Gaetano Lo Mònaco, João Ferreira, Luís Guerreiro Pinto ('ascais e Ren7o Dini. 5. ed. Brasilia:UNB, 2004 v. 1. p. 955-957. 
não porque produzam regras para manter-se nessa condição hierárquica. A legitimidade advém não de quem ou porque se detém o poder, mas do majoritário grau de consenso dos integrantes sociais sobre o acerto das escolhas axiológicas daqueles, quanto às finalidades e às formas de se atingir o bem comum.

Contudo, não se legitima uma atuação do poder estatal pelo seu simples comprometimento com o maior ou menor grau de eficiência em se atingir as finalidades traçadas, mas também com a forma pela qual esses fins são atingidos. Caso contrário, para reduzir a pobreza bastaria matar um número significativo de pobres, o mesmo se daria, hipoteticamente, para a redução do analfabetismo e do número de criminosos. Nesse passo se verifica o equívoco da expressão muitas vezes empregada por agentes públicos de que "os fins justificam os meios" O fim pode ser atingido, mas o meio empregado pode torná-lo totalmente ilegítimo.

Tratando-se de crime, a coerção estatal, por excelência, é a sanção penal, a mais severa e estigmatizante das coerções estatais, tanto que, basta a própria existência de uma persecução penal, meio para se saber se alguém é ou-não culpado e deve ser punido, para que a pessoa já fique social e moralmente marcada. ${ }^{12}$

A sanção penal, idealmente, excluídos alguns fetiches punitivos, deve ser pouco aplicada em qualquer sistema juspolítico, por duas razões principais.

A primeira, porque a aplicação da sanção pressupõe o cometimento de um crime, logo, já foi cometido um dano social relevante, que o Estado, em suas várias áreas de atuação (preventiva, extrapenal, educacional, etc.), não conseguiu evitar. Portanto, sua efetivação é uma resposta coercitiva a um outro malsocial que lhe antecedeu (o crime). A segunda, também não se deve aceitar como normal a alta incidência da sanção penal porquanto possa caracterizar uma falta de legitimidade das escolhas político-axiológicas em face de uma parcela (maior ou menor) do grupo social, sendo o crime uma manifestação ilegítima daquela escolha. ${ }^{13}$

Pela relação até aqui exposta entre política e sociedade, percebe-se que a única forma de se reduzir ao mínimo indispensável a aplicação da sanção penal como

12 Já se tornou lugar comum a observação cameluttiana de que o processo penal jả é uma pena que se impõe ao acusado e, por ser um mal em si mesmo, forma o paradoxo de ser necessário infligir um mal (processo penal) a alguém, para se saber se ele é ou-não culpado. Pune-se. portanto, com o processo, muitos inocentes.

13 Historicamente são muitos os exemplos de opções políticas por criminalizar ideologias diversas e ameaçadoras aos intcresses politicos dominantes. No Brasil, ainda está em vigor a Lei de Segurança Nacional, que por muito tempo, rasgando qualquer princípio de legalidade penal e processual penal, servia como pseudo lastro juridico para perseguições políticas. Assim também, no Direito Penal da pessoa, punese e criminaliza-se a pessoa pelo que ela é, não por seu eventual comportamento. Nas relações internacionais atuais, os Estados Unidos da América do Norte estabeleceram a politica de defesa preventiva, pela qual pretende legitimar atuações bélicas contra Estados, dos quais se suspeita possa vir algum ato lesivo. 
manifestação do poder político é buscar uma maior legitimidade para o sistema jurídico criminal. Dessa forma, descartada a utopia de uma sociedade sem Direito Criminal. a única forma de se limitar este ramo do Direito ao aceitável é analisar em que grau (extensão e profundidade) e de que forma deva-se estruturá-lo para atender aos anseios de bem-estar da significativa maioria dos integrantes sociais.

Isso é o objeto de preocupação de uma política pública voltada à área criminal.

3. Política Criminal como parte da Política de Estado: natureza e formulação

Para a presente exposição, deve-se considerar Política de Estado como a mais ampla e perene extensão que se pode dar à preocupação em se apreender os mais significativos anseios sociais e traçar a mais adequada forma de obtê-los, com a maior legitimidade e o menor uso da coerção.

Política de Estado não se confunde, portanto, com Política de Governo, sempre mais limitada no tempo de duração do mandato da classe detentora do poder e da ideologia de seus integrantes.

Não se descarta a força do poder da ideologia como dirigente das escolhas axiológicas dos integrantes do poder. $\mathrm{O}$ que se pretende, tendo em vista o Brasil de nossos dias, é ressaltar que em um país de capitalismo tardio, de instituições públicas a serem refeitas ou até mesmo feitas, ${ }^{14}$ de penúria em áreas tão importantes como a educacional, a saúde pública, a de empregos e salários condizentes com uma vida digna para todos, é se fixar que muito além das ideologias deve-se buscar um mínimo de dignidade humana.

Nesse quartel do humano, a busca e a solidificação de sua mais ínfima dignidade não traz — ou deveria trazer - divergências ideológicas significativas entre partidos políticos seriamente comprometidos com a eliminação dapobreza, da marginalização e redução das desigualdades (art. $3^{\circ}$ da Constituição da República) e com a estruturação sólida de Instituições Nacionais fundamentais.

Nesse aspecto, para além de uma Política momentânea e circunstancial de um governo, mesmo legitimado pelo voto popular de uma eleição, o que se deve buscar

is Tome-se. por exemplo, ao que nos interessa na área criminal, as defensorias públicas criadas pela Constituição da República em 1988 e que até 2006 ainda não existem em todos os Estados da Federação e, em muitos, não têm o minimo estrutural para atender à crescente demanda dos excluidos que lhe procuram como última esperança de orientação e acompanhamento juridico. Nesse contexto de formação incipiente, tardio e insuficiente, destaca-se a Defensoria Pública do Estado de São Paulo, formada apenas no ano de 2006, quase 20 anos após a promulgação daquela Carta Politica. Não fosse pela abnegação incondicional de poucos Procuradores do Estado que passaram a integrá-la c lhe deram o corpo inicial, e sequer teria sido constituida tal instituição no Estado mais rico da Federação. 
é uma Política de Estado, do Estado brasileiro. Política que, dada à precariedade das instituições pátrias, não é tarefa de um governo, mas de vários deles. Traçar uma linha coerente de finalidades, atividades e formas para sua execução que perpasse vários governos, com eventuais divergências ideológicas e sanha por próprias realizações, é o maior desafio nacional.

Uma Política de Estado depende da eficácia de cada uma das porções políticas que a compõem (p.ex., política educacional, política de saúde pública, política econômica, política habitacional, política de emprego, política criminal, etc.), afinal, o Estado não cumpre seu papel de garantidor e promotor do bem comum se, por exemplo, ao lado de uma excelente política econômica mantém uma péssima política educacional ou a par de uma boa política de saúde pública existe uma péssima política criminal. Aliás, a necessária interação e interdependência de cada uma dessas áreas da política torna verdadeiramente impossível se acreditar que possa haver um êxito absoluto em uma área se houver o insucesso nas demais.

O bem-estar da coletividade depende de que o conjunto das suas necessidades seja integralmente atendido e, para tanto, é imprescindivel à Política de Estado atingir um alto grau de eficácia em todos os espectros políticos que a compõem.

A política criminal, portanto, como parte integrante do todo denominado Política de Estado, depende não apenas do êxito das demais políticas públicas, mas, principalmente, e antes, necessita pressupor que haja aquele todo anterior e no qual se insere, uma Política de Estado. Sem Política de Estado clara não há como se definir ou se efetivar uma política criminal. Se o Estado não define seu objetivo primaz (p.ex., redução da pobreza pela distribuição de cestas básicas, incremento educacional da população, aumento das exportações, desenvolvimento tecnológico para aumento da competitividade internacional, setorização da economia, privatização, incentivos fiscais e redução tributária, etc.) e onde alocará seus principais recursos para a realização desse objetivo, não se pode definir uma coerente e integrada política para a área criminal.

Muito se discute se a política criminal tem natureza científica ou é mera técnica. ${ }^{15}$ Por entendermos que a política criminal é espécie do gênero Política e como já está assentado, sem divergências significativas, que a Política tem natureza científica, ${ }^{\text {To }}$ não vemos como se negar àquela espécie a mesma natureza e especificidade de seu gênero.

Para uma análise do debate, seus vários autores e argumentos, v. GALVÃO. Femando. Politica criminal. Bclo Horizonte: Mandamentos, 2000. p. 23 e ss.

16 Sobre o ramo do direito denominado Ciència Politica e sua diferenciação e autonomia em face da Teoria Geral do Estado, v. FILOMENO. José Geraldo Brito. Teoria geral do ıstado e ciéncia politica. 4. ed. Rio de Janeiru: Forense Universitäia. 2001. p. 18-19. 
Considerar a política criminal como mera técnica de aplicação de meios para a diminuição da criminalidade "estimula seu descompromisso para com a sistematização e coerência do conhecimento teórico sobre as estratégias de combate ao crime. Um pensamento acientifico pode ser influenciado pelas emoções do momento, e a política de repressão estatal não pode ser orientada por simples correntes de opinião. Em muitos exemplos pode-se constatar que a opiniăo pública exerce nociva influência sobre a produção normativa, fazendo com que questões importantes du vida social sejam tratudas de maneira inadequada" 17

Por isso não se pode admitir o argumento alimentado por uma falsa $\mathrm{e}$ formal lógica de que. se a população quer a pena de morte ou a redução da menoridade penal, cabe ao legislador atender esse reclamo. mais ou menos majoritário. da sociedade. O erro lógico dessa assertiva está em que a manifestação popular está viciada e manipulada, porquanto a ela não são informadas as reais causas e conseqüências. p.ex.. da violência advinda das crianças e dos adolescentes, as experiências ineficientes de outros paises quanto à pena de morte, que vão desde a sua definitividade diante de erros judiciais, até a constatação de que, se a pena já é um instrumento de marginalização dos pobres - bastando ver o público alvo dos presídios - não terá público diverso a sanção da pena de morte, além do fato de não reduzir em nada a criminalidade. A opinião pública somente terá validade e será legitima quando a todos for dado conhecer, em igualdade de condições, os argumentos favoráveis e contrários a cada instituto, notadamente a causa da criminalidade, da criminalização/persecução e suas costumeiras vitimas.

Mesmo se abandonarmos a vinculação da política criminal com a Política de Estado, veremos sua inegável relação de interferência e dependência com o Direito (Direito Penal e Direito Processual Penal, mais aproximadamente), este também uma ciência. "A política criminal é verdadeira ciência, que se ocupa em configurar o direito penal de modo a constituir-se no instrumento mais eficaz para a preservação da harmonia social. A política criminal lança mão de dados fornecidos pela criminologia sobre a realidade social e o funcionamento da justiça criminal. A criminologia, ciência empírica que estuda o crime como fenômeno social, assegura que a tomada de decisões da política criminal possui uma base cientifica e não arbitrariamente limitada. A política criminal não é ciência à maneira das ciências exatas, mas no sentido aproximativo, que orienta as investigações sobre as estratégias de combate à

17 Galvão. Femando. Politica criminal. Bclo Horizonte: Mandamentos, 2000. p. 26-27. 
criminalidade na direção da fórmula mais eficaz para o estabelecimento de uma sociedade ideal. De qualquer modo, ciência" 18

Política criminal, como parcela da Política de Estado e como ramo científico voltado ao exame do "crime" como elemento inevitável na vida social, deve ser entendida como o conjunto de decisões técnicovalorativas sobre os instrumentos, regras, estratégias e objetivos do exercício institucionalizado do poder político estatal pelo uso da coerção penal em face de condutas indesejadas. ${ }^{19}$

A política criminal também possui duas fases para sua realização: uma fase de colheita de informes e, a segunda fase, referente à implementação das mais condizentes estratégias para seu combate. Na primeira fase recolhem-se dos dados teóricos de outros ramos do saber, tais como a Criminologia. ${ }^{20}$ a Sociologia e demais ramos que informem sobre aspectos relevantes da origem e funcionamento da atividade criminosa, áreas diversas como a administrativa, a econômica e a educacional, aptas a fornecer elementos sobre o atual estágio e grau de estruturação das instituições sócioadministrativas para atuarem na prevenção/repressão do crime. Na segunda fase, recolhidos os elementos, deverá haver uma escolha sobre qual o melhor meio dentre os existentes e realizáveis para implementar ao menor custo (social, econômico, político e jurídico) a melhor consecução do bem-estar social.

Os agentes da política criminal deverão buscar dados teóricos e práticos para a sua orientação e escolher os mais eficazes e viáveis para o seu êxito. Deverão aliar ciência e realidade sócio-econômica para a escolha do melhor direcionamento em prol da maioria do corpo social.

Nesse contexto, que deve orientar toda e qualquer política pública, a política criminal não pode estar voltada para a defesa dos interesses das classes detentoras do poder. Não pode servir de instrumento para elas utilizarem o poder político para eliminar focos de resistência ideológica ou para a proteção de bens jurídicos somente a ela pertencentes, tudo em detrimento da maioria.

Agir politicamente em favor dos interesses da classe dominante e não da maioria do grupo social deturpa o exercício do poder político e deslegitima as escolhas que serão impostas por força de lei, carecendo o corpo normativo do aumento da coerção

18 GAlVÃO, Fernando. Politica criminal. Belo Horizonte: Mandamentos, 2000. p. 28-29. Em sentido contrário, afirmando não ser a politica criminal una ciência v. BINDER, Alberto M. Política criminal de la formulación a la práxis. Buenos Aires: Ad-Hoc, 1997. p. 28 e ss.

15 Nesse sentido, v. BINDER, Alberto M. Politica criminal de la formulacion a la práxis. Buenos Aires: AdHoc, 1997. p. II e ss.

20 Sobre a relação necessária e fundamental entre politica criminal, criminologia e direito criminal v.. por todos, ZAFFARONI. Eugenio Raúl. Politica criminal lativamericana: perspectivas e dyuntivas. Buenos Aires: Hammurabi, 1982. 
estatal (sanção penal) para sua manutenção. A política criminal, como instante de escolha valorativa, poderá ser mais ou menos legitimada na medida em que, mais ou menos, aproxime-se do consenso da maioria do grupo e não dos interesses do poder institucionalizado.

Por outro lado, a escolha deverá ser a mais técnica possível, dado o caráter científico desse ramo político.

O pressuposto científico auferido da Criminologia, Sociologia e demais ramos do saber deverá oferecer um leque de opções teóricas à solução da criminalidade, devendo a realidade fática (p.ex., cultural, escassez de recursos, estágio estrutural das instituições públicas e privadas envolvidas ou auxiliares) indicar qual a escolha mais apropriada dentre as várias soluções possíveis.

Assim, se a politica criminal materializa-se mais notadamente na elaboração de leis (penais e processuais penais), para tê-las como instrumentos de busca de um controle da criminalidade, não se operacionaliza ou atinge êxito apenas com base na edição legislativa. Não se nega que a lei é a melhor forma de se decidir e impor coercitivamente as decisões valorativas, que determinada política criminal entende como certo ou como inaceitável. Porém, uma política criminal não se limita à edição legal e não se sustenta apenas nisso."

Qualquer política criminal inicia seu maior ou menor êxito quanto mais preciso for o âmbito de sua atuação. Assim, um Estado que entenda por bem nãocriminalizar o uso de entorpecentes, mas apenas o tráfico ilícito dessas substâncias. limitará sua atuação punitiva, deixando para outras esferas de atuação política do Estado (p.ex., saúde pública, educação, assistência familiar, etc.) o cuidado com os viciados. Não punir o viciado não significa ausência de política criminal. apenas a ausência de sanção penal, ficando o trato da questão a outras áreas de atuação pública. A política criminal existe e, exatamente por existir, faz escolhas e valora que não é punindo que eliminaremos o uso de entorpecentes.

Nesse exemplo citado, a política criminal, por optar não-tipificar a conduta do viciado como crime, escolhendo não-editar norma penal para tal comportamento, não deixou de tratar o problema da criminalidade, uma vez que ao lado do vício muitos outros crimes podem ser cometidos (p.ex., lesão corporal, morte. roubo, furto, além obviamente do tráfico). Mas exige que outra interferência estatal não-punitiva mostre-se eficiente no trato do viciado, a fim de que a estrutura punitiva se direcione para atuações em que for a ultima ratio.

21 Não se pude confundir legalidade com legitimidade, nesse suntido, inclusive buscando a sistematização da legitimação do poder, v. FARIA. José Eduardo. Poder e' legitimidade. São Paulo: Perspectiva, 1978. p. 77 e ss. 
A politica criminal tem dois grandes campos de preocupação: um, destinado a definir o que é crime ou o que não merece a tutela penal, ficando, neste último caso, reservado o seu tratamento ao campo extrapenal; o outro, que objetiva estabelecer meios e instrumentos para lidar com o crime. ${ }^{22}$

A política criminal inicia-se, portanto, antes da atuação legislativa e não se esgota apenas nela. Boa política criminal é aquela que, examinando as causas do crime, atua de modo a que ele não surja. Péssima política criminal é aquela que se limita à estruturação de um amplo e exauriente aparato legal punitivo, isto porque, não há segurança pública em se punir o crime, pois, para que ele seja punido, é necessária a sua ocorrência. Segurança pública não nasce de uma boa estrutura punitiva, pois se aceitamos que a estrutura punitiva somente entra em ação após o cometimento do crime, a segurança pública já foi abalada. A sanção penal, sempre posterior ao crime, é apenas um mal estatal diante de um outro mal anterior.

Daí o verdadeiro absurdo nos discursos políticos que afirmam que a segurança pública será protegida com penas mais altas e maior espectro de criminalização (p.ex., com a redução da menoridade penal). Tais medidas, muitos mais midiáticas do que científicas, não atingem o cerne da questão, qual seja, como fazer com que pare de crescer o número de crimes? Quais os meios eficazes para evitar que determinadas infrações se reduzam em determinados grupos sociais (p.ex., os crimes de homicídio em comunidades mais pobres e os crimes de sonegação fiscal entre os mais abastados)? Onde está o erro e onde se deve atuar para que o fato ilícito não surja?

Essas são as questões para as quais o conhecimento teórico deverá oferecer opções (p.ex., reduzir a carga tributária), a fim de que diante da realidade prática (p.ex., necessidade de um aumento na arrecadação devido ao déficit estatal e da necessidade de se investir em áreas fundamentais como saúde e educação) possa o agente detentor do poder político optar por reduzir a ocorrência dos crimes por uma atuação preventiva (p.ex., aumentar e melhorar o sistema de fiscalização tributária a fim de desestimular ou neutralizar atos não desejados — o não-recolhimento do tributo devido).

Uma política criminal ideal, portanto, deve fixar como pressupostos que o crime é acontecimento inevitável e que a sanção penal deverá ser usada com comedimento e para casos extremos. Nesse espaço assim estabelecido, deve buscar em outras áreas do conhecimento as informações necessárias, tanto das causas e formas de manifestação da criminalidade quanto da realidade prática sobre a qual direciona sua

BINDER, Alberto M. Politica criminal de la formulación a la práxis. Buenos Aires: Ad-Hoc, 1997. p. 2830 . 
análise. Para que, ao final, com toda a gama de informações colhidas, opte, diante de uma Política de Estado mais ampla e com outros espectros de atuação pública, atuar de forma produtiva e preventiva na redução da criminalidade.

A politica criminal é um instante presente de colher experiências passadas para a fixação de bases para um futuro mais adequado à sociedade. Será um futuro mais adequado quanto mais científica e menos casuística e emergencial for a análise axiológica presente. Decidir por impulso, para uma questão pontual e desvinculada de uma clara Política de Estado, é tudo que uma política pública não deve fazer, notadamente a política criminal.

4. Politica Criminal brasileira: principais causas e conseqüências de sua inexistência

No Brasil não há política criminal, nos termos como exposto no item anterior. Na realidade nunca houve, desde a época do descobrimento. O que houve foram pequenos impulsos ou aparentes tentativas, sempre embebidas por forte influxo político autoritário. Assim, como hiatos históricos, podemos citar o período do Primeiro Império, outro no Governo autoritário de Getúlio Vargas e. por fim, no periodo posterior ao regime militar. de meados da década de 60 , até final da década de $80 .^{23}$

A política criminal desses períodos não estava fundada na existência de uma maior ou menor legitimidade nas escolhas valorativas empreendidas pelos detentores do poder, mas na definição clara de objetivos por eles definidos. A coerência na produção legislativa e a clara fixação de objetivos do poder político, não significa consenso. Nesse passo, o poder político tinha força, não-autoridade. ${ }^{24}$ Para ambos (coerência legislativa e fixação de objetivos), falta o elemento essencial a qualquer exercício de poder político: a legitimidade que somente nasce do consenso da maioria do grupo, ao entender que os objetivos empreendidos pelo poder político não são dele, mas da coletividade, e é em seu benefício exercido.

Tomando como exemplo os regimes autoritários acima citados, percebc-se com clareza que a maior legitimidade de uma política pública não advém apenas da maior ou menor consecução dos fins, mas inclusive, e principalmente, de como eles são atingidos.

Para uma análise dessas pálidas e momentâncas incursðes de "politicas criminais brasileira" v. v estudo de DELMAS-MARTY, Mireille. Os grandes sistemas de politica criminal. Tradução Denise Radanovic Vieira. São Paulo: Manole, 2004. p. 198 e ss. para os sistemas de politica criminal totalitários e autoritárius.

24 Sobre a diferença entre força c autoridade no excrcicio do poder politico e sua rclação com a idéia de legitimidade, v. FILOMENO, José Geraldo Brito. Teoria geral do estado e ciência politica. 4. ed. Rio de Janeiro: Forense Universitária. 2001. p. 127 c ss. 
Em todos esses momentos históricos, houve uma efetiva diminuição da violência urbana - de cunho politico ou-não. Mas, esse aparente êxito, foi causado por uma forte atuação repressiva que, se não se limitou a matá-los, utilizou-se, em boa medida, desse meio de atuação, para incutir o medo em todos os integrantes sociais, pela crença de um efetivo e integral controle ideológico e comportamental, gerando a sua eliminação, caso posto em dúvida. Esse método violento de atuação para redução da criminalidade (política, ou-não) nunca angariou legitimidade, prova disso é a pouca duração dessa espécie de exercício de poder.

A política criminal, portanto, não extrai sua legitimidade apenas do maior ou menor êxito na redução da criminalidade, assim como também não se legitima pela coerência legislativa. Insista-se, a legitimidade de qualquer política pública somente advém da correta apreensão por parte do poder político dos reais anseios sociais e da mais apropriada escolha e digna forma para a sua consecução.

Descartados esses períodos de coerência legislativa por força do autoritarismo repressivo e reveladas as razões de não poderem ser consideradas sequer minimamente legítimas políticas públicas, voltamos ao ponto inicial: nunca houve no Brasil uma efetiva política criminal.

Diante desse fato, resta-nos tentar identificar quais são as causas dessa ausência histórica e as conseqüências atualmente sentidas.

\subsection{Principais causas da ausência de politica criminal no Brasil}

A mais importante causa da ausência de uma política criminal brasileira e da qual todas as demais decorrem - é que jamais existiu uma real e efetiva Política de Estado no Brasil. Sem uma matriz fundante e diretiva de objetivos maiores, extraídos do consenso do povo brasileiro (Política de Estado), não há como se situar, dentre as demais políticas públicas, um âmbito claro e uma finalidade segura para uma política criminal.

Sem qualquer incentivo governamental ou de grandes instituições privadas, o trabalho dedicado de muitos cientistas desenvolve a Criminologia, a Sociologia e demais ciências auxiliares para o fornecimento de elementos teóricos para a formação de uma boa política criminal. Essa insuficiência de um estudo nacional e amplo das causas do crime, porém, não é o maior óbice para a falta de uma Política Criminal de Estado. Não lhe falta material teórico-científico.

O maior obstáculo é a falta de uma visão perene e definida para o atuar estatal. Não há instituições públicas modernas e aptas a responder às exigências do 
mundo moderno, ${ }^{2 \varsigma}$ não se atua na eliminação perene dos focos da violência, não se investe em outras áreas públicas (p.ex.. saúde, educação, fiscalização administrativa, controle administrativo das atividades econômicas) a fim de reverter a sensação de falência do Estado, com a correspondente crença de que todos devem atuar egoisticamente e com vistas apenas aos próprios interesses.

A falta de uma Política de Estado gera um desagregamento social contínuo, porquanto os indivíduos não vêem nas instituições públicas uma atuação definida e em prol do bem comum. Por esse prisma, aumenta-se a conviç̧ão de que cada um deve agir individualmente na defesa e manutenção de seus interesses e, no instante em que os integrantes do corpo social assim atuam, cresce o fosso das desigualdades e a sociedade começa a se dividir em castas sócio-econômicas inimigas e, por conseguinte. promotoras de uma violência interna diante da qual o poder político deverá optar a qual lado destinará sua tutela penal. Como há classes mais e menos poderosas econômica, social e politicamente, será sempre a classe mais poderosa a que melhor influirá nos desígnios estatais e, portanto, terá seus interesses mais bem tutelados.

Isso pode ser comprovado se notarmos que, nos últimos anos. os crimes patrimoniais foram os que tiveram as penas mais ampliadas. Quem tem patrimônio e quer vê-lo tutelado: as classes com mais poder econômico ou as mais desapercebidas de recursos? A resposta é tão simples quanto é evidente a constatação do porquê a falta de Política de Estado é a mais significativa causa de ausência de política criminal.

Outra causa da falta de política criminal. muito provavelmente por decorrência da causa anterior, é opção do poder político em deixar-se pautar por questões criminais pontuais, de caráter emergencial e midiático.

Nessa perspectiva, o Estado, sum rumo certo e definido. atende às exigências sem critérios cientificos ou minimamente coerentes, mas por requisições midiáticas de emergência. ${ }^{26} \mathrm{O}$ total descomprometimento da mídia e das vítimas de atos violentos não poderia provocar a desorganização do atuar público, que deveria estar pautado por razões científicas. Porém, o apelo popular e midiático seduz o atuar dos

2s Veja-se, por exemplo, para o tema criminal, o aparelhamentu tecnulógicu e o investimento humano destinado às polícias estaduais (militar e civil). A falta de remuneração condizente com a importância do papel desempenhado pelos policiais somente se compara com a ausencia de um eficaz e continuo treinamento segundo novas e mais modernas técnicas de investigação e prevenção dos crimes. Não se está afirmando que não existem iniciativas pontuais. o que se afirma - em alto e bom som - é que esse investimento (salarial e em aperfeiçoamento) nào é uma política pública constante que sequer dure um governo. quanto mais uma política que perpasse vários governos e se torne uma Politica de Estado.

26 Como estudos de referências sobre o direito criminal emergencial, suas causas e danosidades v. CHOUKR. Fauzi Hassan. Processo penal de emergência. Rio de Janeiro: Lumen Juris, 2002. e MOCCIA, Sérgio, La perenne emergenza: tendenze autoritarie nel sistema penale. Nápoles: Ed. Scicntifichc Italiane, 1997 e. ainda do mesmo autor, "Emergência e direitos fundamentais" 
detentores do poder, que buscam no "atendimento emergencial" e acientífico uma legitimidade, também aparente, e que ele (Estado) nunca conseguiu obter.

Porém, o que o Estado não percebe - e já deveria ter percebido, uma vez que o Brasil vive essa legislação de emergência há quase duas décadas - é que. ao assim agir, a legitimidade momentânea que aparentemente pensa receber é, com o tempo, transformada em frustração e mais revolta deslegitimante. Isto porque o Estado, agindo por impulso popular e midiático, produziu uma legislação sem com isso aparelhar as instituições que deverão aplicá-la e fiscalizá-la, sem dizer dos focos de incoerência jurídica e inconstitucionalidade que toda a legislação feita às pressas produz.

$\mathrm{Na}$ busca de uma aparente legitimidade, o Estado que aceita uma política criminal emergencial só aumenta sua ilegitimidade.

A falta de uma Política de Estado, em cujo bojo possa se inserir de modo claro uma política criminal, assim como o legiferar de modo desorganizado e emergencial propicia o surgimento de outra causa: a atuação desordenada dos operadores do Direito Criminal e dos juristas.

A falta de rumo (Política de Estado) e o atuar estatal espasmódico (legislação criminal de emergência) permitem e são potencializados pela atuação desordenada dos operadores do Direito na área criminal e pela inexistência de uma base jurídico-científica sólida que indique uma direção clara ao aparato repressivo penal e as áreas em que não seria necessário.

Excluindo-se as vaidades acadêmicas e os fetichismos punitivos travestidos de técnica hermenêutica, o que se vê é uma desordem no discurso técnico dos operadores do Direito Criminal. Tal desordem se inicia por uma má formação técnica e se potencializa pela seletividade punitiva, uma vez que as características pessoais dos participantes do processo e das vítimas determinam uma maior ou menor "eficiência" na punição.

Não se afirma que a Ciência do Direito, como ciência humana, não admita e não creş̧a com a divergência ideológica. O que se está a destacar, como causa da ausência de política criminal, é a total falta de coerência, muitas vezes de um mesmo julgador ou Tribunal, ao tratar as partes, as vítimas ou os suspeitos/acusados não pelo que fizeram ou por critérios técnicos já desenvolvidos em outros casos, mas por quem sejam. $^{27}$

Mais uma vez, e também por essa nova causa, aumenta a deslegitimidade do sistema jurídico-criminal e a certeza da ausência de uma política criminal, já que o

${ }_{27}$ Para isso basta consultar os vários repertórios e obras especializadas em glosar arestos dos vários Tribunais brasileiros e que, invariavelmente, para cada ponto da legislação criminal, notadamente a processual penal, apresenta ao menos duas correntes dispares na aplicação de um mesmo dispositivo. 
trato dos envolvidos no processo por critérios pessoais, e não por critérios técnicos, gera em toda a sociedade a sensação de impunidade. Para os desvalidos, a impunidade se manifesta na certeza da marginalização constante e de que o sistema jurídico criminal é mais um obstáculo a vencer na sua desigualdade para com os mais abastados. Para esses, por sua vez, a impunidade se manifesta em uma certeza de que está acima da lei e que o sistema repressivo jamais o atingirá, nem aos seus. ${ }^{28}$

Também integrante dessa causa, advinda dos operadores do Direito Criminal e dos juristas da área, é o exercício de suas atividades, não pela forma determinada em lei, ou pela qual seria a mais condizente com uma boa aplicação da lei, mas como é "possível" ou seja, costumam alegar a escassez de recursos e a falta de estrutura pública, como maneira mais fácil e cômoda, para se furtarem da sua obrigação funcional em buscar a melhor aplicação da justiça.

Se a massa processual é descabida, não buscam preservar a qualidade dos julgamentos, mas dar cabo da maior quantidade possível. Para incrementar tal inversão de prioridades, os Tribunais estabelecem como critério de promoção a "produção quantitativa", jamais a "qualitativa" Nesse diapasão, justifica-se o discurso que cada um faz o que pode, mas é exatamente por causa dessa deletéria e conveniente conformidade que não se ataca a raiz do problema por meio de uma política criminal.

Para ilustrar essa causa da falta de política pública para o tema "criminalidade" cite-se o fato público e notório de que, em São Paulo, o Estado mais rico da Federação, há dezenas de milhares de mandados de prisão a cumprir pela Polícia. Todos sabem disso, autoridades e cidadãos, e nada é feito. Até mesmo porque, se todos mandados fossem cumpridos, não haveria onde colocar os presos. Não há presídio para todos e nem mesmo recurso para construir presídios na mesma velocidade com que se condenam pessoas. O que está errado? A quantidade de condenados soltos ou a falta de presídio? Falso dilema que a Imprensa sempre nos impõe. O que está errado é não se neutralizar a produção maciça e continuada de crimes, pela aplicação de uma política criminal que os elimine em suas origens. Discutir, entre tantas outras medidas, meios mais eficazes de tornar as penas substitutivas à prisão mais interessantes, tanto para o condenado quanto para a sociedade e o Governo.

Essa dissonância hermenêutica e acadêmica e o conformismo dos operadores do Direito Criminal impede a formação de uma massa crítica coesa e

Desse sentimento advém as clássicas frases: "a justiça é para os ricos"; "a cadeia é feita para os pobres"; "você sabe com quem está falando?", "Quem ć você para me dizer o que devo fazer?". "Vá procurar a Justiça!", "Você sabe o que eu posso fazer com você na Justiça?", "Não converso com você, fale com meus advogados!", "Quem é esse policialzinho (com variações para juizinho ou promotorzinho) para me prender (ou processar)?", "Comigo é na bala e aqui a 'Justa' não vem!". etc. 
desinteressada de juristas e operadores do Direito, preocupados com o bem comum e não em ver vencedora sua tese acadêmica ou sua posição processual. Não se forma, com isso, um grupo de pensadores do Direito para implementar uma política criminal por meio de uma codificação renovada e comprometida com os desafios futuros.

A tolerância e o conformismo impedem que, no Brasil, extraia-se desses erros do passado as necessárias lições para a formulação de um sistema mais eficaz para o futuro. Impede-se, portanto, a elaboração de uma efetiva política criminal.

4.2. Principais conseqüências da ausência de uma política criminal no Brasil: uma crise de legitimidade

Muitas e profundas são as conseqüências da falta de uma política criminal. Porém, para manter-se uma coerência expositiva, indicar-se-á as mais ligadas às causas acima referidas, relacionando-as entre si, sendo uma, ao mesmo tempo, decorrência e potencializadora dos prejuízos das outras.

A inexistência de uma política criminal devido à falta de uma Política de Estado faz. com que se imagine que aquela espécie de política pública limita-se à formação de um sistema legislativo penal (Direito Penal e Direito Processo Penal, incluído neste a execução da pena). A falta de políticas públicas orientadas ao auxílio e redução das causas e efeitos do crime (p.ex., por uma política social, educacional, habitacional, de saúde pública, econômica, tributária, etc.) relegam à legislação criminal uma tarefa que não é dela, qual seja, a solução de conflitos e litígios não necessariamente, ao menos em um primeiro instante, criminosos. Porém, pela falta de atuação daquelas outras esferas de política pública não-punitiva, as insuficiências individuais e os conflitos interindividuais se agravam e evoluem até receberem, mais cedo ou mais tarde, o selo de "atos criminosos"

O Direito Criminal deixa seu caráter subsidiário e fragmentário (ultima ratio) e passa a ser utilizado como instrumento público (primeiro e único) para a solução de conflitos sociais. Isso quando, por desvio de perspectiva política, não se criminaliza atos de insurgência social por melhores condições de vida, como ocorre, às vezes, com a tipificação de movimentos sociais.

Cria-se, com o auxílio ou a ignorância conivente da mídia e de discursos de lei e ordem, uma confusão entre o social e o criminal e qualquer forma de reivindicação, protesto ou violência social (p.ex., protestos em filas de postos de saúde ou da previdência fechados ou $\mathrm{em}$ greve) passa a ser tratada com instrumentos punitivos. Nesse passo, ingressam alguns juízos ideológicos dos operadores do Direito - terceira 
causa acima pontada - os quais utilizam o aparato penal ou o persecutório penal para iniciar ações penais e determinar prisões cautelares. como forma de aplacar a insatisfação gerada pela violência, na "alteração da ordem desejada"

Como decorrência dessa primeira conseqüência e reflexo da segunda causa acima apontada (edição excessiva e pontual de legislação criminal de emergência e assistêmica), a sobrecarga de indevidas atribuições à legislação criminal gera uma idêntica sobrecarga nas instituições judiciárias e persecutórias (Polícia e Ministério Público), o que faz com que não se tenha legislação e aplicadores suficientes para cuidar de todos os conflitos e insuficiências sociais. Até mesmo, porque o Direito Criminal não tem. por natureza, a velocidade e a finalidade para o qual o empregam (resolução de demandas de fundo social, não-criminal).

Ao se deformar a legislação criminal e sufocar seus operadores. todo o sistema perde em legitimidade por duas razões: primeira, porque com a sobrecarga indevida, deixa de atuar de modo eficaz para o que foi destinado - apurar e julgar atos efetivamente danosos à sociedade -; segunda, porque como o Direito Criminal não resolve problemas sociais, econômicos, tributários ou políticos, há uma desilusão daquela parcela da população que foi levada a crer que, com ele, todos esses problemas seriam resolvidos.

Essa crise de legitimidade quanto ao sistema criminal, com o tempo. passa a se espalhar para os operadores do Direito Criminal e para os demais agentes públicos. como um todo. Nesse instante, chegamos à terceira e talvez mais deletéria conseqüência da ausência de política criminal no Brasil.

Os operadores do Direito Criminal e o Estado, em uma última tentativa de recuperar a legitimidade perdida, e visando reverter a sensação de descrédito que lhe são atribuídos pela população, aumentam o aparato repressivo tanto em extensão - punindo cada vez mais e novos comportamentos - como em profundidade - aumentando as penas e recrudescendo a política penitenciária.

Com isso, completa-se o círculo vicioso.

O Estado faz exatamente o oposto do que se espera de uma política criminal eficiente. Primeiro, porque, sem analisar e atacar as causa do crime, utiliza-se da legislação criminal como único instrumento de sua política pública. Segundo, porque vulgariza a sanção penal, mais importante meio de coerção estatal, para finalidades a que ela não foi idealizada, tais como tentar suprir insuficiências públicas e individuais e resolver conflitos sociais que poderiam e deveriam ser neutralizados, ou solucionados, por outras áreas do Direito, e com outras políticas públicas. Terceiro, porque, ao deslegitimar o aparato criminal (por sua equivocada utilização para a solução de 
conflitos sociais), busca se legitimar com um maior incremento da carga punitiva. Quarto, como o Direito Criminal é ineficaz ao fim para o qual é disposto, o aumento da carga punitiva só faz aumentar o número de condenados e presos e, por seu caráter seletivo, leva ao descrédito social aquele que deveria ser o mais parcimonioso e respeitado instrumento de poder político de um Estado moderno, o sistema punitivo.

Como decorrência última desse círculo vicioso em que o Estado se deslegitima como um todo frente à população, temos que os integrantes do corpo social, na medida de suas forças e condições, passam a lutar e defender de modo individualista seus interesses. Os menos favorecidos, por meio de saques públicos diante de qualquer distúrbio social, por mortes em número elevado nas periferias das cidades, por violências interfamiliares e intracomunidades, para solução de conflitos sociais não encaminhados ou deixados de lado pelo Poder Público. tudo a aumentar a sensação de insegurança pública. Os mais abastados entendem-se "autorizados" pela ineficácia e deslegitimação do aparato público, a contratar segurança privada, armar-se e proteger-se, muitas vezes, por meio de construções que mais segregam e tentam afastar outros grupos sociais para além das muralhas de suas moradias.

Tudo a propiciar, por várias razões e efeitos, o desagregamento do tecido social, decorrência indefectível do comportamento individualista gerado pela falta de uma política pública apta a atingir um de seus fins precípuos, qual seja, a coesão da sociedade para a consecução do bem-estar coletivo.

\section{Constituição e Tratados Internacionais: matrizes para o início}

Diante de todo o antes referido, percebe-se que o Sistema JuridicoCriminal brasileiro carece de legitimidade. Essa constatação, absolutamente inegável, não pode constituir ponto final de um debate, mas seu início. A questão, portanto, é buscar um marco consensual que sirva de esteio seguro e legítimo para o debate a ser travado, que sirva de pressuposto epistemológico e limite de atuação aos detentores do poder político.

Toda política criminal que deseja ser racional - no sentido de ser organizada por critérios claros, precisos e consagrados pela experiência humana - e legítima - no sentido de haurida e destinada à mais ampla parcela da população — deve construir suas bases sobre dois pilares: o Direito e o homem.

Direito para além e aquém da lei posta, mas sem dela prescindir como forma mais segura de organização social. O Dircito deve ser considerado cumo o conjunto de prescrições (normativas e decisórias) claras e destinadas a conferir, a todos 
os integrantes sociais e aos agentes públicos, a segurança necessária para seu atuar autorizado e para limitar a intervenção dos exercedores do poder político.

Mas de nada adiantaria um bom Direito se ele não guardasse a mínima afinidade com as pessoas às quais se destina. A pessoa humana é o princípio e o fim de qualquer atividade pública; portanto, deve ser o primeiro ponto das preocupações e o destinatário final das atividades políticas.

Ambos os pilares referidos nos conduzem à escolher a atual Constituição brasileira como marco inicial legítimo e duradouro, estruturado e resultante da evolução das experiências humanas.

Esta escolha não se faz por imperativo hierárquico de ser a Constituição a lei fundamental de um país e a partir da qual todas as demais devem ser construídas harmonicamente. Uma vez que, apenas por essa perspectiva hierárquica, poder-se-ia escolher constituições autoritárias ou elaboradas para a defesa de um determinado grupo, em prejuízo dos demais. Não é o que ocorre com a nossa atual Constituição.

Para demonstrar seu caráter humanitário e destinado à formação de uma Nação una e dirigida ao bem comum, basta observar seus princípios fundamentais e pelos quais se assevera, como preocupação primeira, ser o Brasil um Estado Democrático de Direito, do qual todo poder emana do povo e é em seu nome exercido, e, em cujos fundamentos destacam-se, ao que nos importa nessa exposição, a dignidade da pessoa humana e o pluralismo político (art. $1^{\circ}$ ). Também entre seus princípios fundamentais inserem-se seus objetivos reitores, quais sejam: construir uma sociedade livre, justa e solidária, garantir o desenvolvimento nacional, erradicar a pobreza e a marginalização e reduzir as desigualdades sociais e regionais e, por fim, promover o bem de todos, sem preconceitos de origem, raça, sexo, cor, idade e quaisquer outras formas de discriminação $\left(\operatorname{art.} 3^{\circ}\right.$ ).

Destes princípios fundamentais, ninguém pode dissentir, não por força de ser norma constitucional, mas por força da humanidade inquestionavelmente contida em seus fundamentos e objetivos.

A constatação estruturante e humanitária de nossa Constituição ainda pode ser observada pela consonância que guarda com os Tratados Internacionais de Direitos Humanos, consagrados pelos povos da atualidade como conquistas do homem após as experiências bélicas das duas grandes guerras mundiais, da primeira metade do século $\mathrm{XX}$

Os Tratados Internacionais de Direitos Humanos tem como sua base histórica a experiência do que pode acarretar o autoritarismo, a desconsideração pelo homem, a utilização do poder político para fins egoísticos e o desejo de supremacia de 
um grupo sobre outros. Nada foi mais desastroso e nada foi mais contundente. A morte, a tortura, a expropriação da liberdade e da dignidade humana, no seu mais simples e elementar sentido, nunca foram tão intensas e disseminadas por tantos países. Guerras de povos e irmãos que, como um dos poucos, bons e perenes frutos, deixou à humanidade a experiência de que, somente com diplomas Internacionais de fixação mínima de uma pauta de garantias ao homem, podemos estruturar sistemas juspolíticos positivos ao desenvolvimento humano.

Nesse sentido, nossa Constituição não é apenas o reflexo dos textos internacionais já existentes sobre os direitos e garantias fundamentais do homem, mas está inteiramente permeável a inserir no ordenamento jurídico brasileiro, por força dos parágrafos existentes em seu art. $5^{\circ}$, outros princípios, direitos e garantias fundamentais existentes ou a serem elaborados para o desenvolvimento do homem.

Assim, nossa atual Constituição e os Tratados Internacionais de Direitos do Homem devem servir como o único arcabouço legal e esteio epistemológico legítimos, para ser o formal ponto de partida para a elaboração de uma política criminal.

Mas, apenas essa base constitucional não é suficiente para a formação de uma política criminal brasileira. É necessário, ainda, não olvidar as características e desejos do povo brasileiro.

A participação popular na discussão de políticas públicas, notadamente a política criminal, é de fundamental importância, por ser uma necessária via de duas mãos, e, pela qual, não apenas os representantes populares dirão o que esperam da política criminal, mas deverão ouvir e compreender que a cultura até hoje entranhada, de que todos os seus problemas são resolvidos pela legislação criminal, deverá ser rechaçada. Assim como rechaçados também deverão ser os preconceitos, de muitos "senhores do saber", de que a violência vem da pobreza e de que toda forma de violência é crime e deve ser punida.

O fato da maior obrigação pela construção de uma política criminal ser dos agentes públicos, exatamente por estarem nessa condição, não significa dizer que se deva levar em conta apenas o que entenderem conveniente a seus próprios interesses ou das classes que neles projetam mais significativa influência. Os preceitos constitucionais e internacionais de promoção do bem comum, igualdade e dignidade da pessoa humana não se dirigem apenas aos interesses dos detentores do poder político. Devem atingir a todos integrantes da comunhão social, pobres e ricos, fracos e fortes, suspeitos e inocentes, culpados e injustiçados, condenados e vítimas, prejudicados e beneficiados.

5.1. Necessária superação do falso dilema: "eficiência versus garantismo" 
A construção de uma política criminal tendo em vista o homem e o bem comum deve, necessariamente, consistir em uma mudança de mentalidade.

$\mathrm{Na}$ área processual penal, por exemplo, uma nova política criminal somente poderá ser efetivamente discutida se estivermos maduros para superar um falso dilema que pseudoideologias teórico-academicistas insistem em construir, qual seja, uma inconciliável dicotomia entre eficiência e garantismo.

Por ignorância ou má-fé, insiste-se em difundir a idéia de que sistemas garantistas são ineficientes, pois dificultam o rápido julgamento do culpado. Afirma-se, velada ou expressamente, que a execução das normas decorrentes dos princípios do devido processo legal, da ampla defesa, do contraditório, da inadmissão da prova ilícita (inclua-se aqui, p.ex., a confissão mediante tortura, a busca e apreensão sem ordem judicial, a quebra do sigilo de dados sem ordem judicial, etc.), da liberdade no curso do processo como regra, entre outras, torna o processo demorado, custoso e improficuo.

Descartadas as pessoas que professam esse entendimento para fazer valer uma vaidade acadêmica ou um fetichismo punitivo, as demais c de boa-fé esquecem que a estrutura do atual Código de Processo Penal, inegavelmente inquisitivo, está em completa dissonância com a estrutura acusatória determinada pela Constituição e única passível de incorporar aquela base principiológica constitucional e internacional.

Não há dicotomia entre efíciência e garantias constitucionais, o que há é uma inconciliável dicotomia entre a estrutura legal do Processo Penal brasileiro atual e a Constituição. A superação daquele falso dilema passa, necessariamente, pela elaboração de uma nova legislação processual penal.

Nessa nova legislação, princípios como a oralidade e simplicidade das formas processuais serão a regra, porquanto assim é no sistema acusatório. A responsabilidade dos operadores do Direito crescerá na medida em que deverão ser mais aptos a decidir e atuar em processos mais céleres. As partes e o juiz terão seus papéis bem delineados e suas atribuições simplificadas, sem superposição de tarefas ou repetição de atos. Os atos investigativos deverão ser norteados por uma maior capacidade investigativa, a fim de reduzir o número de ações penais infundadas. Deve-se criar um espaço para o consenso em matéria de crimes de menor potencial ofensivo, cuja seleção e tratamento deve ser proveitoso para os participantes daquele consenso e das vítimas.

Esse pseudodilema, característico da área processual penal, encontra pares não menos significativos na área penale penitenciária, e todos são óbices para a formação de uma nova política criminal. Isto porque não representam apenas alterações legais, mas mudanças de mentalidades e hábitos. Significam perda de poder para alguns 
operadores, aumento de responsabilidade para todos operadores e exposição da falta de preparo técnico de outros tantos.

5.2. Uma proposta para início de uma Política Criminal brasileira na área processual penal

O desafio está em como conciliar todo o antes expendido em um projeto - ou ao menos em um início de projeto — de formação de uma política criminal.

Sem olvidar que política criminal não se limita à legislação criminal, mas reconhecendo-a como o mais significativo instrumento de exercício c implementação daquela política pública, volta-se, aqui, a atenção para a área processual penal.

A questão, à qual se pretende oferecer uma resposta é: Como viabilizar a construção de uma política criminal para a área de processo penal, com a participação popular efetiva e com base nos princípios constitucionais e internacionais de direitos do homem?

Por meio da formação de uma pauta mínima, inicial, vinculativa e estruturada, de aplicação daqueles princípios fundamentais destinados ao processo penal, em cada parte dessa área jurídica. Essa pauta, nesse primeiro instante, não é um Código. Mais se aproximaria da experiência de outros países de uma lei delegante. por meio da qual o Poder Legislativo formula regras mínimas e vinculantes que devem ser obedecidas e, a partir das quais, uma comissão de juristas é formada para a redação de um Código.

Durante os trabalhos da comissão deve haver consultas e debates, não-só entre os integrantes da comissão, mas entre representantes populares e dos operadores do Direito. das mais variadas funções, a fím de colaborarem na redação de uma legislação que a todos atingirá. Posteriormente, finalizados os trabalhos da comissão, a redação é enviada ao Poder Legislativo que, por meio de uma comissão revisora técnica, verificará a fidedignidade entre aquela pauta autorizadora e vinculativa e a redação apresentada de Código.

Essa pauta, fixadora de limites e pressupostos, deve fornecer segurança para as necessárias mutabilidades e adaptações de uma política criminal, na área processual penal. perene e duradoura. Assim, deverá ter base imutável e sólida de princípios e regras orientadoras para uma nova legislação. Nesse sentido, como pórtico mais seguro dentro do sistema jurídico nacional. deverá ter como conteúdo primaz as "cláusulas pétreas" dispostas na Constituição e dirigidas ao processo penal. 
No Brasil, muito se discute se nossa Constituição autoriza ou-não a elahoração de lei delegante para a formulação de um Código de Processo Penal. Novamente, não nos podemos deter por questões práticas facilmente superáveis. Para além da discussão, se há ou-não autorização constitucional para elaboração formal daquela espécie de lei delegante, melhor que se inicie a formulação daquela pauta mínima e vinculativa, como marco inicial de uma nova política criminal, clara, constitucional, permeável à participação popular e setorial, enfim, projete-se um início e um marco seguro.

Sem esse início, não há como começarmos a demonstrar racional, técnica. pacifica e legitimamente a nossa mais completa insatisfação com "o que" e "de que forma" está se conduzindo a produção legislativa para a árca criminal brasileira.

\section{Conclusão}

O Brasil vive uma crise de legitimidade de instituições e políticas públicas. Não apresenta uma Política de Estado e, portanto, expõe suas instituições às incertezas e ineficiências inerentes a um atuar desorganizado e desestruturante. Perde a cada dia e em todas as áreas de atuação a necessária legitimidade informadora de qualquer política pública.

Na política criminal, o Brasil não está colhendo melhor sorte.

Exatamente porque não tem uma Política de Estado, perene e abrangente para todas as áreas da sociedade. não possui a necessária coordenação entre as várias áreas públicas. A política criminal não tem definidos os seus limites, uma vez que não sabe que parte dos problemas está afeita, p.ex.. à política social, à educacional, à econômica ou à tributária, e o que é, efetivamente, matéria criminal. O Estado não sabe utilizar as políticas públicas não-punitivas para reduzir o âmbito da política criminal, não sabe, enfim, utilizar com parcimônia a mais importante arma que possui para exercer seu poder político em busca da coesão social, qual seja, a sanção penal.

A legislação criminal é utilizada para muitas questões às quais é imprópria. Direito Penal não resolve conflito social e processo penal não serve para aplacar a sanha da mídia. Quando assim são usados mostram-se ineficientes e levam ao descrédito as instituições judiciárias, persecutórias e os agentes públicos em geral.

Como efeito danoso e mais deletério, o Estado e seus agentes. percebendo a ineficiência do aparato criminal, não reconhecem que ela advém de seu emprego indevido. mas entendem que a ineficiência está na pouca força punitiva utilizada. Asšim, 
desviando ainda mais a função da legislação criminal, produz leis punitivas de emergência e assistêmicas.

A única forma de reverter esse processo histórico, que atualmente ganha uma contundência capital - com a exposição às claras da ineficiência pública de contenção da criminalidade e neutralização das origens do crime - é haver uma mudança de mentalidade pela qual se proceda a uma ruptura com o processo ciclópico e desarrazoado de produção legislativa.

Nessa mudança de mentalidade está incluído o reconhecimento de que ninguém é capaz, sozinho, de gestar e gerir uma necessária revolução na formação de uma política criminal. As vaidades e arrogâncias devem ser postas de lado, as mais firmes convicções teóricas precisam ser revistas e os preconceitos formados para o que seria "eficiente" ao século XX devem ser repensados se ainda encontram atualidade, não para o início do século XXI, mas para muitas de suas décadas.

Patriótica e humildemente devemos aceitar que tudo o que até agora fizemos, incentivamos, consentimos ou toleramos está errado. Devemos reconhecer nossos erros e insuficiências para com a população que sofre sempre e a cada dia as violências produzidas pelo sistema criminal que hoje existe.

Precisamos, enfim, recomeçar.

Nesse contexto se coloca a expressão "caos" do título do artigo. Caos entendido, mitologicamente, não como um deus "mas um principio, o do começo confuso de todas as coisas, a imagem do que existia antes dos deuses, antes dos mortais $e$ de onde tudo foi gerado. Caos gerou Érebo e a Noite. Depois, da sua massa confusa, surgiram o Dia e Éter, com o primeiro desabrochar da luz indispensável à eclosão da vida" 29

São Paulo, dezembro de 2006.

Referências

BATISTA, Nilo. A política criminal d'A Utopia e a Maldição de Hedionduras. In: Novas tendências do direito penal. Rio de Janeiro: Revan, 2004.

BINDER, Alberto M. Politica criminal de la formulación a la práxis. Buenos Aires: Ad-Hoc, 1997.

. Iniciación al proceso penal acusatório. Buenos Aires: Campomanes Libros, 2000.

SCHMIDT. Joêl. Dicionário de mitulogia grega e romana. Tradução de João Domingos. Lisboa: Edições 70, 1994. p. 61 . 
BOBBIO. Norberto [et al]. Dicionário de politica. Tradução Carmem C.. Varrialle, Gaetano Lo Mônaco, João Ferreira, Luis Guerreiro Pinto Cascais e Renzo Dini. 5. ed. Brasília:UNB, 2004, v. I. COMTE-SPONVILlE, André. Dicionário Filosófico. Tradução Fduardo Brandão. São Paulo: Martins Fontes, 2003.

CHOUKR, Fauzi Hassan. Processo penul de cmergència. Rio de Janeiro: Lumen Juris, 2002.

DELMAS-MARTY. Mireille. Os grandes sistemas de politica criminal. Tradução Denise Radanovic Vieira. São Paulo: Manole, 2004.

FILOMENO, José Geraldu Brito. Teuria geral do estado e ciência politica. 4. ed. Rio de Janeiro: Forense Universitária. 2001.

FARIA, José Eduardo. Poder e legitimidade. São Paulo: Perspectiva, 1978.

FRANCO, Alberto Silva [et al]. Código de processo penal e' sua interpretação jurisprudencial doutrina c jurisprudência. 2. ed. rev.. atual. e ampl. São Paulo: Revista dos Tribunais, 2004.

GALVÃO. Fernando. Politicu criminal. Belo Horizonte: Mandamentos, 2000.

MOCCIA, Sérgio. La perenne emergenza: tendenze autoritarie nel sistıma penale. Nápoles: Ed. Scientifiche Italiane, 1997.

. Emergência e defesa dos direitos fundamentais. Revista Brasileira de Ciências Criminais, n. 25, p. 58-91, jan./mar. 1999.

SCHMIDT, Joël. Dicionário de mitologia grega ¿ romana. Tradução João Domingos. Lisboa: Edições 70, 1994.

7.AFFARONI. Eugenio Raúl. Politica criminal latioamericana: perspectivas e dyuntivas. Buenos Aires: Hammurabi, 1982. 